\title{
Universal versus targeted approaches to prevent early education gaps. The Netherlands as case in point
}

\author{
Paul P. M. Leseman (iD · Pauline L. Slot
}

Published online: 13 May 2020

(C) The Author(s) 2020

\begin{abstract}
There is strong evidence that high quality early childhood programs targeting disadvantaged groups can have lasting benefits and high returns on investment. The evidence for universal programs, however, is less conclusive. The present paper examines the claims of universal and targeted approaches to preventing early education gaps. First, recent findings on the universal unitary early education and care systems in Denmark and Norway are reviewed regarding the educational quality and compensating effects on disadvantaged children. Second, the advantages and disadvantages of targeted approaches are discussed, focusing in particular on the trade-off between cost-effectiveness and aggregated impact on society. Third, the Dutch educational equity policy will be analyzed as a case in point to illustrate the dilemmas, contradictions and paradoxes of equity policy pertaining to targeted and universal approaches. Finally, as a synthesis of the findings, two complementary approaches are outlined: a universal within targeted and a targeted within universal approach.
\end{abstract}

Keywords Education gaps · Early childhood education · Equity policy · Universal · Targeted

Prof. Dr. P. P. M. Leseman ( $\bowtie)$

Department of Child, Family and Education Studies, Utrecht University, Heidelberglaan 1, 3584

CS Utrecht, The Netherlands

E-Mail: p.p.m.leseman@uu.nl

Dr. P. L. Slot

Utrecht University, Heidelberglaan 1, 3584 CS Utrecht, The Netherlands

E-Mail: p.1.slot@uu.nl 


\section{Universelle versus zielgruppenorientierte Ansätze zur Verhinderung früher Bildungsdisparitäten - Das Beispiel der Niederlande}

Zusammenfassung Es existieren etliche qualitativ hochwertige Angebote und Programme in der frühen Bildung für benachteiligte Kinder, deren langfristige Vorteile für die Kinder wie die Gesellschaft empirisch gut belegt sind. Weniger überzeugend sind die Wirkungsnachweise für universale Angebote und Programme. Im vorliegenden Beitrag werden die Ansprüche von universalen und zielgruppenorientierten Ansätzen betrachtet, Bildungsbenachteiligungen vorzubeugen. Dazu werden neuere Befunde zur Qualität in frühkindlichen Einrichtungen und zu kompensatorischen Effekten für benachteiligte Kinder aus den universalen und einheitlichen Früherziehungssystemen in Dänemark und Norwegen vorgestellt. Anschließend werden die Vor- und Nachteile zielgruppenorientierter Ansätze diskutiert, insbesondere im Hinblick auf das Kosten-Nutzen-Verhältnis und den aggregierten Effekt für die Gesellschaft insgesamt. Ausführlicher wird dann die niederländische Fairnesspolitik vorgestellt, um daran beispielhaft Dilemmas, Widersprüche und Paradoxien einer solchen Politik hinsichtlich universaler und zielgruppenspezifischer Ansätze und Programme zu illustrieren. Als Synthese der bisherigen Befunde werden schließlich zwei komplementäre Ansätze skizziert: das Anreichern universaler Anteile innerhalb von zielgruppenspezifischen Ansätzen sowie den Ausbau zielgruppenspezifischer Anteile bei universalen Ansätzen.

Schlüsselwörter Bildungsbenachteiligung · Frühkindliche Bildung · Erziehung und Betreuung · Fairnesspolitik · Universale Ansätze · Zielgruppenorientierte Ansätze

\section{Introduction}

There is strong evidence that high quality early childhood programs targeting disadvantaged groups can have lasting benefits and a high economic return on investment for society (Heckman et al. 2010; Reynolds et al. 2011), but the lion share of this evidence comes from a few well-designed and well-implemented model programs in the USA which involved specific groups in extremely disadvantaged circumstances. The evidence for universal early childhood education and care (ECEC) programs at scale in the USA and other national contexts is less conclusive and seems to differ by age (e.g., Datta Gupta and Simonsen 2010; Bartik 2014; Havnes and Mogstad 2015; Cascio 2017; Kottelenberg and Lehrer 2017; Van Huizen and Plantenga 2018). Some studies find long-term benefits in the general population, at least for children in the 4- to 6-years age range (for the USA: Gormley 2008; Cascio 2017; for Spain: Felfe et al. 2015; for a general overview: Melhuish et al. 2015). Other studies find no effects of ECEC in the general population (for Canada: Kottelenberg and Lehrer 2017; for Norway: Havnes and Mogstad 2015). Some studies find even negative effects in the general population on middle long term social-emotional outcomes if ECEC is used intensively from a young age (for the USA: Vandell et al. 2010; for Denmark: Datta Gupta and Simonsen 2010). 
A consistent finding for universal ECEC programs, however, is that they are at least beneficial for children from disadvantaged backgrounds, also when the program starts early and is intensive (Cascio and Schanzenbach 2013; Germany: Felve et al. 2015; Havnes and Mogstad 2015; Kottelenberg and Lehrer 2017; Cornelissen et al. 2018; for a meta-analysis, see Van Huizen and Plantenga 2018). Through the beneficial effects of a universal program on disadvantaged children, the return on investment in universal ECEC can still be positive, although smaller than in case of targeted programs (Magnuson and Duncan 2016; Van Huizen et al. 2019). Critical for the return on investment in a universal system is enrolling as many children from disadvantaged backgrounds as possible.

With regard to the accessibility and use of ECEC, universal systems with one type of provision, early entitlement to use, means-tested fees or free of charge, and generous public spending are frequently thought to be superior, enrolling more children from a disadvantaged background at an early age and providing them with high quality education and care (Cascio 2017; Ünver 2019). By virtue of this, universal early starting unitary ECEC systems are often thought to be the best option for countries to redress early education gaps and to generate impact at the scale of society by reducing social inequality substantially. However, there are caveats and counterfactual findings.

The present paper examines the claims of universalism and its alternative, targeted policies. Related to this, the paper critically examines the role of public education institutions which in most countries are in charge of delivering universal services. We will first discuss recent evidence from two Scandinavian countries, Denmark and Norway, both with a universal ECEC system with entitlement from age 1 and generous public funding. We will review the overall emotional and process quality found in nationally representative samples of ECEC centers in these countries, compare this with findings in other countries with split, privatized systems, and discuss the evidence for compensating, gap-reducing effects on disadvantaged children's development. We will then review the advantages and disadvantages of targeted approaches and discuss the trade-off between cost-effectiveness and impact. Finally, we will discuss the Dutch educational equity policy of the past decades as a case in point to illustrate the main dilemmas, contradictions and paradoxes of equity policy pertaining to both targeted and universal approaches, but also to identify possibly promising strategies.

\section{Universal or targeted? Arguments and evidence}

\subsection{Universal, unitary ECEC to address early education gaps}

One caveat to universal systems with early onset and early entitlement is that they are expensive at the macro-scale with the risk that a trade-off will be sought between quantity (supply, accessibility, affordability, use) and quality, at the expense of quality. This makes universal systems vulnerable in less wealthy countries or in less wealthy times when governments have to take austerity measures. Targeted programs, in contrast, seem more cost-effective and to require (far) less macro- 
spending, but there is an important counter-argument here too concerning the total aggregated impact of targeted equity policy for society (Barnett 2010; Bartik 2014), as will be elaborated further below.

A second caveat is that universal unitary systems often have little flexibility, provide a 'one-size-fits all' program that often, not necessarily or intrinsically but as an empirical fact, is modelled after the primary school system with relatively large classrooms, directive teachers, predominant whole group activities combined with teacher-absent free play time, and opening hours that do not fit parents' working hours (OECD 2006). Examples of this type of provision are the École Maternelle in France (universal, affordable, for children of age 2-6), the kindergarten in Flanders, Belgium (universal, free of charge, age $2 \frac{1}{2}-6$ ), and the kindergarten in the Netherlands (universal, free of charge, age 4-6, part of the primary school system since 1985). In these systems the universal character of the system is limited to the key provision and use of this provision often needs to be combined with complementary forms of formal or informal care before and after school to fit the working hours of parents in dual-earner families.

There are examples of universal ECEC which are less closely modelled after a traditional primary school, with either smaller groups than usually found in school-alike systems or with big groups but more favorable children-to-teacher ratios that enable sub-grouping to provide an exploratory and pretend play-based holistic curriculum. Examples of the latter model are the municipal Scuola del Infanza in Northern Italy, with famous examples in the cities of Reggio Emilia and Pistoia. These preschools, moreover, provide a whole day/whole week arrangement fitting the working hours of parents. Still, the age of onset and legal entitlement is 3 years, thus the system does not cover the 0 - to 3-years period and, in case of dual earner families, needs to be complemented by ECEC (or informal care) before age 3. Moreover, the costs for the municipalities are substantial.

There are examples of universal unitary systems that start really early (age 1, in combination with generous parental leave policies until age 1) and provide a whole day and whole week program that is not school-alike, with low costs for parents. These examples are the systems of Denmark, Norway and Sweden. Using ECEC in these countries is not compulsory, but the majority of the children goes to the local community ECEC center after the first birthday. Percentages of use under three years of age are over 70\% (in Denmark) and also low-income groups participate to a high degree (Pavolini and Van Lancker 2018). The costs for the government, however, are substantial and even in these countries with a very strong ECEC tradition that rests on broad social consensus, there is a risk that with a change in the political landscape or an economic crisis, austerity measures lead to lower quality (Naumann 2011).

Important for the current discussion is the recent evidence that the Nordic systems may be of good quality but perhaps not as good as often thought. A recent representative study of the Norwegian universal-unitary ECEC system, the GoBaN study, involving 206 classrooms with about 1000 children, using the ITERS-R (Harms et al. 2006) and ECERS-R (Harms et al. 2005) as observation instruments to assess quality, revealed average total scores of 3.9 (ITERS-R, for care of children up to age 2.5 years), respectively 4.2 (ECERS-R, for care from age 2.5-6 years) on 
scales from 1-7, which is considered moderate at best: between the conventional benchmarks of 3 'insufficient' and 5 'good' (Bjørnestad and Os 2018; Kleppe and Bjørnestad 2019). In comparison, studies with the ITERS/ECERS-R in countries with privatized and marketized multi-form systems revealed equal or even higher quality scores, such as Australia (average total score 4.9 for the ITERS/ECERS-R combined, based on five moderately representative studies including one from privatized ECEC in New Zealand; Vermeer et al. 2016), North-America (average total score 4.1, based on 25 studies; Vermeer et al. 2016), England (average total score 5.3 for both ITERS-R and ECERS-R in a large representative sample; Melhuish and Gardiner 2017) and recently the Netherlands (average total score 5.3, based on a national representative sample of 128 centers for daycare for 0- to 4-year-olds in 2017-2018; Slot et al. 2018a).

In addition, Slot et al. (2018b) used the CLASS Pre-K (La Paro et al. 2008) in a large scale representative study of ECEC quality in Denmark, involving 260 classrooms and 3132 children between ages 3 and 6 . The scores for emotional support (based on ratings of the affective classroom climate, teacher's sensitivity, regard for children's perspectives and behavior guidance) on a similar scale from 1-7 were high in Denmark (on average 5.9), but for instructional support (based on ratings of teacher's stimulation of children's concept development, provided scaffolding feedback, and language modelling) rather low (on average 2.5). In comparison, scores on the CLASS Toddler (La Paro et al. 2011) in the recent representative study of the Dutch privatized and marketized ECEC system pertaining to children from 2-4 years of age were lower regarding emotional support, on average 5.4 (still above 'good'), but higher regarding instructional support, 3.2, respectively (Slot et al. 2018a). Relatedly, a Dutch study in (public universal) kindergarten (235 classrooms) for 4- to 6-year-olds revealed average scores of 5.4 and 3.3 on the CLASS pre-K (Veen et al. 2017).

Nordic systems also show segregation by socioeconomic or immigrant background (as the systems in other countries do), especially in urban areas. Data from preschools in Denmark reveal that classrooms have on average almost $12 \%$ children with a non-Danish immigration background (Slot et al. 2018b), with large variation between urban and rural areas, and between neighborhoods within urban areas. Remarkably, in Denmark, a larger share of disadvantaged children in the ECEC classroom is significantly negatively related to the observed emotional and educational quality (CLASS Pre-K scores), with medium effect sizes, whereas findings from the privatized split systems in the Netherlands, Portugal (partly privatized) and the UK show the opposite pattern: equal or higher quality, overall, for disadvantaged children compared to non-disadvantaged children (Slot et al. 2015). For example, the ECEC system in the Netherlands is characterized by a targeted early education policy for disadvantaged children, resulting in enhanced participation of these children from age $2 \frac{1}{2}$ years onwards and on average higher quality in ECEC centers with more disadvantaged children (Leseman et al. 2017; see below).

Finally, evidence suggests that early arising gaps in language skills, found between immigrant and non-immigrant children in Denmark at age 2 (Højen et al. 2019) or 3 (Bleses et al. 2018), and at age 2 between low- and high-SES and immigrant and non-immigrant children in Norway (based on the longitudinal studies 
BONDS and MoBa; Zachrisson and Ribeiro 2018) remain rather stable during the preschool period and do not reduce before the introduction into primary school, while large representative cohort studies in the Netherlands (pre-COOL; Leseman et al. 2017; Van Huizen 2018; see also below) and the UK (Millennium Cohort Study; Skopek and Passaretta 2018) show substantial reduction of the gaps in language skills, at least for migrant children, as a consequence of participation in ECEC. Bleses et al. (2018) report on a large scale country-wide RCT study in Denmark, involving the previously mentioned sample and an additional number of other centers, with 7120 children aging 3-6 years in total, aiming at improving language and preliteracy education in the Danish ECEC system. Significant, but small, much smaller than expected, overall effects of the intervention were found on several language and literacy outcome measures regardless the background of the children, but no interaction effect of the intervention with minority language background or family SES, indicating that the initial gaps between disadvantaged and non-disadvantaged groups in language and preliteracy skills did not diminish, not in the intervention group nor in the control group, indicating no catching-up. The authors explain the small overall effects and the lack of catching-up effects by the low exposure to explicit language education in the Danish ECEC system and point to the reluctance on part of the teachers to provide this kind of instruction (Bleses et al. 2018, p. 357; see also Datta Gupta and Simonsen 2010).

A different pattern of findings, but related to the question whether universal measures can be effective in reducing early gaps, is reported by Cornelissen et al. (2018) who analyzed the effects of the expansion of highly subsidized universal half-day ECEC programs for 3- to 6-year-olds in the German state of Lower Saxony in the nineteen-nineties. Whereas the expansion led to increased participation of all children but especially of children from low-SES and immigrant background, the latter groups still participated least (later enrollment, lower participation rates in each of the three consecutive ECEC years). Relating statewide school-entry assessment data to data on preschool use (vs. alternative forms of care, including home care), the authors find, what they call, a 'reversed selection effect': children who tend to participate least, would benefit most from using the provision, and vice versa. The reversed selection effect was especially pronounced for Turkish immigrant children who often do not speak German at home. Furthermore, based on the findings and model simulations, Cornelissen et al. (2018) propose that mere expansion of universal ECEC for 3- to 6-year-olds is not likely to substantially increase the participation of disadvantaged groups.

\subsection{Targeted policy and targeted programs}

Targeted programs, according to a review, are most costs-effective and lead to lower macro-costs (Akgündüz et al. 2015) and, also important to consider, support a more fair distribution of society's collective wealth, because targeted programs redistribute collective tax money to those most in need (Bartik 2014; Van Lancker and Van Mechelen 2015). Investment in universal provision, in contrast, benefits also non-disadvantaged children, the more so, the more these children make use of the provision relative to children from disadvantaged groups, which is usually the case 
in full-day childcare (Van Lancker and Ghysels 2012; Van Huizen and Akgündüz 2016). A different, but related finding is reported by Blanden et al. (2016) who analyzed the effects of the introduction of $12.5 \mathrm{~h}$ free ECEC provision for all children in the UK in the period 2002-2007, as an instance of universal ECEC policy. Using school readiness and school achievement register data, the authors report only small, smaller than expected, positive effects of the expansion on children at primary school entrance which disappeared by age 7 . The explanation, according to Blanden and colleagues, is that the extra funding led to only a small increase in use of ECEC in places and even less in hours, but instead mainly replaced privately funded ECEC use by publicly funded use, benefitting the higher income groups most who already used ECEC but on their own costs.

There are important caveats to targeted programs too. Targeted programs tend to strengthen segregation tendencies (admitting children from disadvantaged backgrounds only) and to lead to concentration of disadvantages in centers and classrooms (Vandenbroeck 2015). This limits the opportunities for disadvantaged children to learn from non-disadvantaged children, for example children who are relatively skilled speakers of the national language (Henry and Rickman 2007; Justice et al. 2011; De Haan et al. 2013; Reid and Ready 2013; Weiland and Yoshikawa 2014), increases the load put on teachers (Lee et al. 1998), lowers achievement standards and teacher expectations (Agirdag et al. 2012), may not attract the best teachers or be simply less academically focused (Cascio 2017; however see for counter-evidence Dotterer et al. 2013).

The major caveat concerns the definition of 'disadvantaged' and the boundaries that are set to the groups of children who are eligible for extra support. The paradox here is that the narrower the definition of target groups (for example, only the most severely deprived are eligible for extra support), the higher the return on investment but also the smaller the total aggregated impact of the policy on society. If only, say, the 5\% most deprived children and families are selected, the return on investment in provision for these children and families might be high (so do it), but the total impact on society might be rather modest simply because the proportion of children getting extra support is small (more is needed). Moreover, if only the most severely deprived children get extra support in the form of targeted ECEC programs they will subsequently end up in primary schools, and at a later stage in secondary schools, with other children from the same or similar neighborhoods who were less severely but still noticeably deprived, however not enrolled in a preschool program. In this case, there will be less peer-learning and other spill-over effects compared to a situation in which a larger group of children received the extra support, improved in skills, and thereby constituted an environment which was more conducive for development and learning (Barnett 2010; Bartik 2014).

\subsection{Targeted within universal, universal within targeted}

Considering the arguments pro and contra universal versus targeted approaches, the conclusion seems to be: try to take the best of both. Universal approaches to the extent that they (inevitably) lead to moderate overall quality (against already high public costs), while lacking extra impulses to attract disadvantaged children and 
provide them with compensating high quality education and care, should be complemented by targeted measures. Targeted measures should be based on a broad instead of narrow definition of who is in the target group so that even when implementing purely targeted programs the overall impact on society can be substantial because pertaining to larger numbers of children. Practically, this may suggest that an approach that focuses on demographic areas (neighborhoods, municipalities, regions) with a moderate to high representation of target children (targeted approach), based on a broad definition of who is at risk, and that includes all children in these areas in a program of high quality (universal approach) is promising. Alternative or complementary approaches could be to provide universal ECEC from age four or five until primary school starts (considering the positive evidence for this age range), but targeted programs in the period before (Bartik 2014), or to include in early universal systems targeted measures to stimulate active outreach to disadvantaged children and families in order to increase their participation, and to provide extra quality, beyond merely creating more supply (cf. Cornelissen et al. 2018).

\section{The Dutch educational equity policy as a case in point}

\subsection{The start of Dutch educational equity policy: two components}

The current Dutch educational equity policy emerged in the nineteen sixties of the past century. Studies had revealed persistent disadvantages of children from low SES backgrounds at the end of primary education upon the transition to the tracked secondary education system at age 12. Whereas the gender gap and also the rural-urban gap had decreased in the decades before, social class remained strongly related to educational success. Large-scale educational innovation projects in a number of the most deprived areas of The Netherlands were initiated under the Educational Stimulation Policy ('Onderwijsstimuleringsbeleid'), focusing primarily on improving primary school education at the curriculum and instruction level. The largest projects were evaluated, however failed to show positive effects in terms of reduced achievement gaps at the end of primary school (Scheerens 1987).

While these innovations to increase equity focused on improving the educational opportunities of children from Dutch low socioeconomic status families, the immigration of labor migrants from Morocco and Turkey, and from former colonies in the Caribbean had begun. In 1985, a new nation-wide educational equity policy was initiated, Educational Priority Policy ('Onderwijsvoorrangsbeleid'), integrating educational equity policy with cultural minorities policy. In 1998, the name of the policy was changed in the Municipal Educational Disadvantages Policy ('Gemeentelijk Onderwijsachterstandenbeleid'). The latter reflects the key role of municipalities in Dutch decentralized education and social policy. Over the years, the Dutch educational equity policy consisted of two main components and this has basically remained so until now:

1. Extra money per disadvantaged child was distributed via lump sum financing to primary schools, based on several criteria or 'weights' of disadvantage (see also 
below), initially: educational attainment of the parents was not higher than lower vocational training, parents had a non-Western ethnic-cultural background, parents were travelers. Schools received extra money if the proportion of disadvantaged children passed a threshold (initially $9 \%$ ).

2. Extra money was distributed to areas (municipalities, regions) with a high concentration of disadvantaged children, based on the average disadvantage-weight of the primary schools in the area, for flanking policies aiming at involving neighborhood welfare organizations and youth care services, implementing homebased education programs and preschool center-based education programs.

In 2003, an evaluation of the first fifteen years of the educational equity policy showed mixed results (Claassen and Mulder 2003; see also Mulder 1996). Using data from four successive cohorts with school achievement measures in the final grade of primary school (at age 12) and information on track position and achievement in the first years of secondary school (at age 13-16), the results indicated a persistent gap by socioeconomic status net of immigrant status and an even larger gap by non-Western immigrant status in the school year 2000-2001. The national standard achievement test at the end of primary school showed stable average scores over cohorts for low SES Dutch children and a small, but consistent rise in scores for the non-Western immigrant children. This slight improvement, however, did not translate into an increased representation of non-Western immigrant children in the higher tracks of secondary education. The conclusion was that the policy was not successful. Driessen (2012) conducted a similar analysis of new cohort data. The results confirmed the previous findings. No clear change in the educational opportunities of non-immigrant low SES children, a decreasing gap (and higher representation in the higher tracks of secondary school) for some groups of immigrant children, but hardly any improvement for children from the largest immigrant groups, the Moroccans and Turkish.

\subsection{Home-based and center-based preschool programs in deprived areas}

The project Education and Social Background ('Project Onderwijs en Sociaal Milieu') in the city of Rotterdam, launched in 1969, was the largest, most rigorously implemented and evaluated early educational stimulation project that involved all primary schools in the poor neighborhoods of the city of Rotterdam. The evaluation revealed that education gaps were already large before children started with formal education in primary school at age 6 . The evaluation also showed that merely improving instruction (according to the school effectiveness approach) would not reduce these early gaps (Leseman 1989; Slavenburg and Peters 1989). Likewise, a national cohort study revealed strong initial gaps (at age 5, the earliest measurement time in this study) that hardly became smaller during primary school. This led to a shift in focus to the early years.

At first home-based programs were introduced. Initial evaluations showed no effects, but a later quasi-experimental evaluation of an improved version of one of these programs indicated the potential of this program to improve social-emotional competence, mathematical skill assessed in Dutch (Van Tuijl et al. 2001), and skill 
Table 1 The four most used comprehensive ECEC curricula in the Netherlands, accredited by the Netherlands Youth Institute, and evaluated as 'theoretically well-designed' and as either 'promising' or 'effective'

\begin{tabular}{llll}
\hline $\begin{array}{l}\text { Curriculum } \\
\text { and } \\
\text { provider }\end{array}$ & $\begin{array}{l}\text { Theoretical sources, de- } \\
\text { velopmental goals, pri- } \\
\text { mary strategy }\end{array}$ & $\begin{array}{l}\text { Brief description of the pedagogical approach } \\
\text { and curriculum content }\end{array}$ & $\begin{array}{l}\text { Market } \\
\text { share } \\
\text { in 2018 } \\
\text { (in \%) } \\
\text { (esti- } \\
\text { mated) }\end{array}$ \\
\hline
\end{tabular}

Piramide Eclectic: Montessori, Vy-

(Cito gotsky, Slavin's Success

groep) for All, emergent literacy

$\&$ numeracy

Holistic development, structured curriculum and teacher training to enable teachers to apply the projects

Kaleidoscoop High/Scope curriculum, (Nederlands Piaget, active learning, Jeugdin- play-based, emergent stituut) literacy \& numeracy Holistic development, professionalization to enable educators to guide children's play within the open frame of the curriculum

Startblokken Leontiev, Vygotsky, Van \& Parreren, activity theory Basison- Holistic development, twikkeling professionalization ap(De Ac- proach to enable educativiteit) tors to design educational activities within the open frame of the curriculum

Uk \& Puk

(CED groep)
Seasonal, daily life and scientific themes, elaborated in 'project books' to support educators (lists of vocabulary and concepts to be taught, enrichment materials, activities, songs), structured program of intentional circle time educational dialogues, exploratory play with special materials, pretend play, small group tutoring, monitoring through assessment with norm-referenced tests

Semi-structured, predefined key-experiences (language-communication, literacy, mathematics), free pretend play, rich play environment with realistic everyday materials but also with literacy and math materials, predictable day schedule and plan-do-review cycle for self-regulated play, additional intentional vocabulary instruction, monitoring through observation

Semi-structured, monthly themes relating to daily life, community activities and occupations, theme-related pretend play, shared reading and educational dialogues in enriched play environments, word lists for educators related to the themes to embed words in natural dialogues, monitoring through observation with a detailed program-specific qualitative observation system

Structured, daily life themes, detailed examples ('scenarios', 'lessons') of circle time and small group playful instruction and reading activities (motor skills, language, literacy, mathematics), dolls Uk (toddlers) and Puk (kindergartners) are voiced by the educator in circle time to elicit communication, occasionally they stay as friends with the children at their homes, monitoring through observations

Several other, sometimes local programs, not always accredited and sometimes focusing only on language and literacy: Boekenstart, Speelplein, Ben ik in Beeld, Doe meer met Bas, and others 
in the home language (Leseman and Van Tuijl 2001). The program, however, was not effective in the lowest educated families due to the low-literacy levels of the mothers who were supposed to implement the program. The program was also not effective with regard to children's learning of Dutch language, due to the fact that the majority of the target families were non-Dutch speaking and chose to work with the version of the program in their heritage language (Van Tuijl et al. 2001; Leseman and Van Tuijl 2001).

In view of these results, in the middle of the nineteen-nineties, also center-based programs for $2 \frac{1}{2}$ - to 6 -year-olds were introduced, building on the existing municipality-run playgroup system (for 21/2- to 4-year-olds; part of local welfare policy) and the kindergarten departments of primary schools (for 4- to 6-year-olds). The results of a quasi-experimental evaluation study of two of these curricula, Piramide and Kaleidoscoop, revealed added value of the special curricula to playgroup and kindergarten 'as usual' (Veen et al. 2000). Later several other curricula became available (see Table 1).

As a corollary, in 2000 , the educational equity policy was extended with regulations obliging municipalities via the area-component and schools via the lump sum component to provide together an accredited center-based early education curriculum to disadvantaged children, spanning the age range $2 \frac{1}{2} 2^{-}$to 6 -years and connecting the municipality-run playgroup system to the kindergarten departments of the primary school system. In addition to the introduction of accredited curricula, funding was supplied for class size reduction or for hiring an additional teacher to increase the staff-to-children ratio. The earmarked funding for early education programs was expanded and the uptake by target groups steadily rose. Currently, about $70 \%$ of ECEC centers for under fours with a half-day or full-day program, or a combination of both, report to use an accredited curriculum (Slot et al. 2018a). Exact figures about the participation of the target group in ECEC (according to the current criteria: children from low SES or non-Western migration background or with a nonDutch home language) are lacking, but in the bigger municipalities participation is reported to be as high as $80-90 \%$ in preschool programs (21/2- to 4-years of age) and nearly $100 \%$ in kindergarten (4- to 6-years).

\subsection{The pre-COOL cohort study}

In 2009 the pre-COOL cohort study was initiated to examine the effects of ECEC on children's development. In this study, over 3000 children of varied backgrounds were followed from age 2 until age 6 (second kindergarten year), with further follow-up measurements at age 9 (grade 3) and 12 (grade 6) (not yet published). These children attended different kinds of provision between age 2 and 4: full-day daycare, halfday pre-kindergarten, daycare or pre-kindergarten with or without one of the official curricula. At age four all children entered the kindergarten departments of primary schools.

The pre-COOL study, first of all, showed large SES and migrant background related gaps at age 2 in Dutch language skills (vocabulary, phoneme discrimination, verbal short term memory), nonverbal executive functions (attention, spatial working memory), and self-control (delay of gratification) (Mulder et al. 2014; Leseman and 
Veen 2016). These early skills were found to be strongly predictive of children's language, literacy and numeracy skills at age 6 (Mulder et al. 2017). Applying growth modelling, children from low-SES backgrounds, non-Western immigrant families and, partly overlapping, with a non-Dutch home language participating in ECEC were found to catch-up substantially in these skills relative to children from non-immigrant, middle to high SES families with Dutch as home language (Leseman and Veen 2016). The average effect size of the catching up effect was for the most disadvantaged group (low-SES and non-Western migration background and nonDutch home language) estimated to be about Cohen's $d=0.75$, thus a strong effect (Leseman et al. 2017).

Furthermore, the catching-up effect appeared to be moderated by characteristics of the provided education and care. Growth in verbal skills was in particular moderated by the use of an official curriculum, like the ones discussed above, and by the quantity of provided play, language, literacy and mathematics activities. Use of an accredited curriculum and a balanced provision of guided play and academic activities was associated with stronger growth in disadvantaged children, but not in children without disadvantages. The strongest moderation effect was found for children with a non-Dutch home language. Growth in executive function skills was in particular moderated by the observed process quality, based on observations with the CLASS Toddler (La Paro et al. 2011): higher instructional process quality and to a lesser extent also higher emotional process quality were associated with stronger growth in executive functions. These effects were found for disadvantaged and nondisadvantaged children, but were stronger for disadvantaged children.

Another study, using register data on class retention as outcome measure, used the expansion in 2012 and 2013 of earmarked subsidy for extra places for disadvantaged children in pre-kindergarten programs in middle-sized municipalities as a natural experiment (Akgündüz and Heijnen 2018). Econometric difference-in-difference analysis revealed that pre-kindergarten education reduced class retention by almost $2 \%$ points (of $10 \%$ ) and the study concluded that the savings due to lower retention and other, realistic but not estimated (future) benefits, would likely outweigh the costs of the extra places. Based on the results of these studies together, the Dutch government decided to increase the budget of about 350 million euro per year for targeted pre-kindergarten with 170 million euro, bringing the total budget to over 500 million euro in 2019 (about $0.0007 \%$ of the GDP and about $4.5 \%$ of the budget for primary education in 2019) and to increase the entitlement for disadvantaged children from $10 \mathrm{~h}$ per week to $16 \mathrm{~h}$ by August 2020.

\subsection{Defining target groups}

The definition of target group of the Dutch educational equity policy has been subject to changes over the years, reflecting changes in society and political climate. In the nineteen-eighties children who had at least one parent educated at the lower preparatory vocational level or had a non-Western immigration background (and in majority another home language than Dutch) were eligible. This led to a sizeable target group of more than $30 \%$ of an age-cohort in 1998. In the late nineteennineties the criterion of immigrant background was dropped. The decision reflected 
the emerging view in the political arena that immigrant status and non-Dutch home language should be disregarded as disadvantaging factors. Also the remaining indicator, parental education level, was changed: eligible were children of whom both parents were not higher educated than the lower prevocational level. These changes resulted in a 'sudden' strong reduction of the target group to $13 \%$ of a cohort in 2010 and $9 \%$ in 2016 (CBS 2016), accompanied by a sharp decrease of the budget for equity policy. Part of this reduction could be explained by the rising education level of parents, but mostly this reduction reflected a political choice that was not substantiated by a real decrease of the education gaps (Driessen 2015).

In addition, studies showed that educational attainment only roughly indicated the quality of the home learning environment, seen as most proximal determinant of children's educational opportunities (Driessen 2015). For example, Oudgenoeg-Paz and Leseman (2017), in a large sample of two-year-olds, found very good specificity (0.95) of the changed target group definition (1.5 standard deviation below the agenorm in language skills at age 4 was the criterion), but a very low sensitivity (0.10), meaning that many children were incorrectly not identified as in need of support (many 'false negatives'). An alternative screening based on indicators of the home language environment (criteria: mother or father having conversations with the child, reading or telling stories to the child and playing language games in Dutch at least three times per week), had both acceptable specificity and acceptable sensitivity $(>0.70)$, and also revealed a sizeable group of Dutch native-born children with environment-based disadvantages.

A recent change in the national target group definition, implemented in 2019, has led to a return of non-Western immigrant background and years of residence in the Netherlands as criteria. Moreover, financial hardship was added. The revised criteria are based on an analysis of cohort and register data collected by the National Bureau of Statistics (CBS), and are empirically established as the most important, but still distal determinants of educational inequality. The target group, thus defined, reveals a 'sudden' increase again, but the government has set the upper-limit of the budget for equity policy to cater for a maximum of $15 \%$ of a cohort.

\section{Beyond curricula: towards effective equitable ECEC systems}

\subsection{Curriculum implementation, segregation and compensatory effects}

The pre-COOL study yielded other interesting findings. The implementation of an accredited ECEC curriculum was expected to result in higher observed educational process quality and more attention for language, literacy and mathematics activities. Overall, however, there was no relation between the use of a curriculum and what was observed and reported in terms of educational stimulation (Leseman and Veen 2016). When broken down by the proportion of disadvantaged children in the classroom, an interesting pattern emerged. In classrooms with less than $33 \%$ disadvantaged children, no noticeable implementation of the curriculum was found. These classrooms did not differ from classrooms without a curriculum. In classrooms with $67 \%$ or more disadvantaged children, in contrast, teachers were observed to provide 
significantly higher educational process quality and to engage more often in language, literacy and mathematics activities (for similar evidence, see Dotterer et al. 2013; Slot et al. 2015).

Here is a critical dilemma for equity policy. Due to the fact that the vast majority of the disadvantaged children in the pre-COOL study were in pre-kindergarten classrooms with a relatively large proportion of disadvantaged children, indicating segregation, they received as a group on average on virtually all indicators high educational (process) quality, higher than non-disadvantaged children on average received. Thus, because of segregated use, the compensatory effect of the ECEC system as a whole in terms of provided quality was strengthened.

\subsection{Regulating hybrid ECEC: the role of values and mission}

The findings relate to the fundamental issue of universal vs. targeted approaches and a key question is why ECEC centers with a low representation of disadvantaged children did not provide extra educational quality, although receiving extra subsidy and having a curriculum available. One possible explanation is that with only a few disadvantaged children in the classroom, it is financially not feasible to arrange for more intensive education or to choose a stronger educational focus. The findings, thus, may point to a dilution effect. Another possible explanation points to the 'organizational culture' of ECEC centers and the role of a value-based social mission of the organization and its staff. In two recent studies we examined this hypothesis.

The Dutch ECEC system for 0- to 4-year-olds used to consist of two main types of provision, full-day childcare to support parents in combining work and care, and half-day playgroups, later turned into pre-kindergarten programs as was discussed above. These services were until the beginning of the 1990s mainly provided by publicly funded municipal welfare organizations (regarding playgroups) and notfor-profit local providers and charities (regarding daycare). To meet the rapidly growing demand of parents for childcare, the child daycare market was privatized in 2005 with the introduction of a new Childcare Act. Originally pertaining to full-day daycare only, with a strong orientation on the labor market function, the system was further harmonized in 2010 by integrating the two formerly separate types of ECEC under a single statutory quality framework. Part of this integration was that all types of provision were entitled to implement the educational equity policy and thus could apply for extra subsidy if meeting the following criteria, which could vary between municipalities: centers should serve a locally specified minimum of children from disadvantaged backgrounds; centers should use one of the accredited curricula; teachers should meet particular additional qualifications. After these successive reforms, a single, universally accessible but hybrid system for the 0- to 4-years age range with multiple functions was created, with commercial as well as public goals, and with incentives to reach out to children from disadvantaged families.

In two studies, Mintzberg's (1983; Quinn et al. 1988) organizational configurations theory was used to examine how ECEC organizations for 0- to 4-year-olds adapted to the demands of the hybrid Dutch ECEC system (Van der Werf et al. 2020; Van der Werf et al. under review). Characteristics of ECEC organizations such as 
legal form, profit goal, center size, type of leadership, attention for in-service professionalization, client-centeredness, diversity policy, social mission, the networking relations with other organizations, and a few other characteristics, were used to identify 'types of organizations'. Data were collected in two nationally representatives samples of ECEC centers providing education and care in the pre-kindergarten period in, respectively, 2012 (pre-COOL; $N=127$ ) and 2017-2018 (LKK; $N=117$; Slot et al. 2018b). Surveys among center leaders provided information on structural and cultural organization characteristics of the centers. Based on this information, cluster analysis was conducted to identify configurations of organizational characteristics, defining different types of organizations. Surveys and structured interviews among ECEC staff yielded information on structural quality characteristics, background of the children cared for, diversity attitudes, and implemented curriculum. Observations with the CLASS Toddler (La Paro et al. 2011) were applied to assess the emotional and educational process quality provided to children.

Cluster analysis revealed three main types of organizations, highly similar at both measurement times, characterized as:

1. traditional not-for-profit professional-bureaucratic,

2. large multicenter divisionalized for-profit, and

3. engaged mixed for-profit/not-for-profit professional organizations, respectively.

Especially the last type, comprising about one third of all organizations, exemplified a new organizational configuration which combined characteristics of both market-driven, professional-bureaucratic and missionary organizations in Mintzberg's terminology. The social-emancipatory mission, the active outreaching to disadvantaged parents and the embeddedness of this type of organizations in local networks with other social services were the most distinguishing characteristics. This type was found to be culturally most inclusive, serving relatively large proportions of low SES, immigrant and language-minority children, while providing the highest emotional and educational process quality. Effect sizes according to Cohen's criterion were medium to large on most measures of quality and inclusiveness (see Fig. 1 for the 2017-2018 results; derived from Van der Werf et al. under review).

Interestingly, both type 1 (bureaucratic) and type 3 (engaged) professional organizations emerged from the former public, municipality-run ECEC system before this system was privatized and harmonized, illustrating the different routes taken by former public organizations to adapt to the new hybrid context. The decisive 'pull factors' for the most effective engaged type 3 organizations to emerge seems to have been twofold:

1. the opportunity to work as a company with increased room for entrepreneurship, flexibility and client-centeredness; and

2. the locally implemented educational equity policy that provides, via the areascomponent, extra subsidy to those organizations in the local ECEC field that commit to the public goals of the equity policy (Van der Werf et al. 2020, in press). 


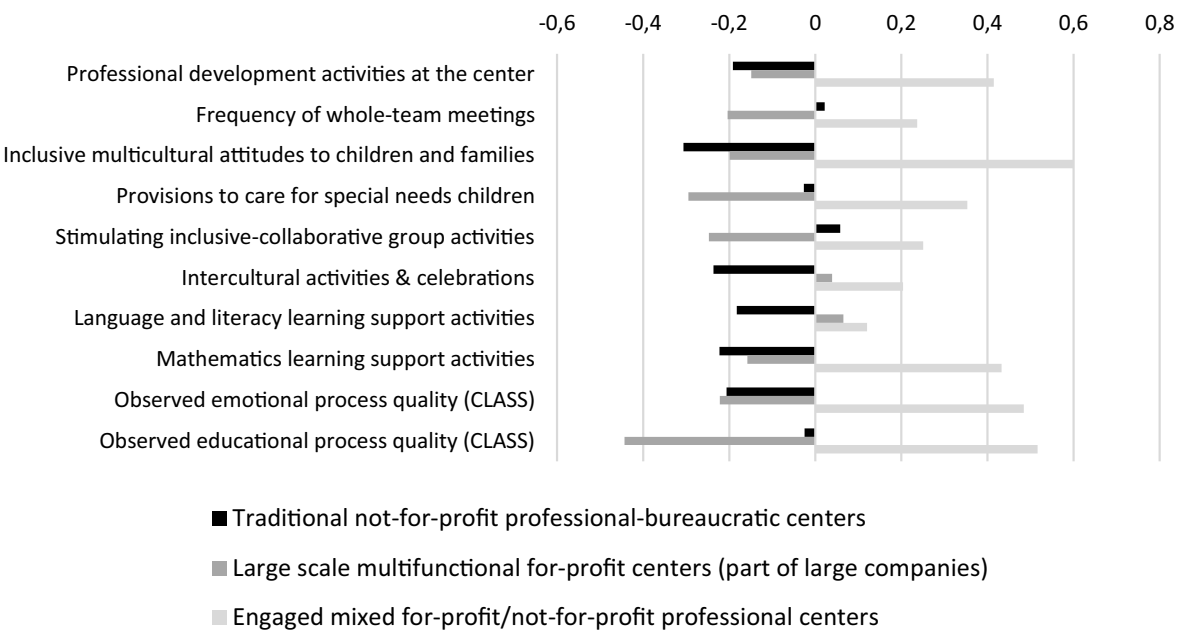

Fig. 1 Quality indicators (z-standardized), based on staff reports and independent observations, by type of ECEC organization ( $N_{\text {centers }}=117$; collected in 2017-2018). (Van de Werf et al. under review)

\subsection{Value-driven targeted policy within universal ECEC}

To summarize the main findings, the fragmented privatized ECEC system in the Netherlands has developed into a universally accessible system for the education and care of children in the 0- to 4-years age range, before universal kindergarten starts. Despite the characteristics of a universal system, ECEC in the Netherlands is not a unitary system with a 'one-size-fits-all' program but a differentiated system that provides different types of care and education, with half-day and full-day programs, either with or without targeted curricula, that fit the divergent needs of different groups of children and parents. The presence of incentives, distributed via the areascomponent of the national educational equity policy, to reach-out to children and families in disadvantaged situations and to provide them with high quality education and care, facilitated the emergence of ECEC organizations that are committed to the goals of equity policy, provide a culturally inclusive climate and high emotional and educational quality, and also succeed in attracting large numbers of disadvantaged children. Paradoxically as this may seem, value-based targeted equity policy within a universal ECEC system seems to work as an effective regulator to ensure that compensatory extra quality is provided to those who need it most.

The findings remind of the critical analysis of the universal childcare expansion in the UK in the period 2002-2007 by Blanden et al. (2016), already referred to above. The universal expansion of free daycare in the UK did not result in clear lasting benefits for all children nor for low-income children in specific. A possible explanation, in view of the findings for the Dutch ECEC system, is that the increase of participation of children from low-income background was mainly realized through expansion of places in lower quality private for-profit ECEC centers without a social mission (Penn 2011; Blanden et al. 2016). 


\subsection{Pre-kindergarten programs vs. kindergarten}

The kindergarten departments of Dutch primary schools are considered part of the ECEC system, providing universal education and care to 4- to 6-year-olds for $25 \mathrm{~h}$ per week and implementing a child-centered pedagogy in relatively large classes. Attendance is compulsory from age 5 . The initial ambition of the educational equity policy, in 2000, to connect pre-kindergarten and kindergarten education more tightly to be able to provide a continuous early education program using one curriculum during the three-and-a-half year period preceding formal education, had to be tempered soon. In 2006, legislation was introduced that led to separation of the educational equity budgets for preschools (via municipalities) from the budgets for primary schools (via school boards), diminishing the coordination power of the municipalities to promote a continuous early education program.

In the pre-COOL study, the cohort of children was followed from pre-kindergaten into kindergarten, where in a similar way the provided quality was assessed with teacher reports and independent classroom observations using the CLASS Pre-K (Le Paro et al. 2008). The findings, first of all, indicated that only about 53\% of the disadvantaged children who received one of the officially accredited curricula in a pre-kindergarten ECEC center, continued to receive this curriculum or another one in kindergarten (Veen et al. 2017). Second, the overall educational process quality was not higher than found in the pre-kindergarten centers on similar measures and lower than found in the engaged pre-kindergarten centers of Van der Werf et al. (2020, in press). Third, there was no relation between the reported use of an accredited curriculum and the observed and reported educational quality provided to the children. Moreover, fourth, the composition of the classroom did not moderate the relation between the use of a curriculum and the provided quality, in contrast to what was found in the ECEC centers. In classrooms with a relatively large proportion of children with a low-SES or migration background, or with many learners of Dutch as second language, apparently no extra language or mathematics learning activities were provided, nor was the observed educational process quality higher compared to kindergarten classrooms with a low representation of disadvantaged children.

Unfortunately no data were available on the structural and cultural organizational characteristics of the primary schools in pre-COOL. Therefore, we could not test whether a similar differentiation existed between primary schools regarding socialemancipatory mission, active outreach and degree of collaboration with other local services. The data, however, suggest that the engaged professional type (providing high quality to disadvantaged children) does not exist in the kindergarten departments of primary schools to the same extent as in the pre-kindergarten hybrid ECEC system. A provocative possible explanation is that primary schools operate in a public system with hierarchic bureaucratic control and little room for entrepreneurship and innovation, resembling the lower quality professional-bureaucratic type of ECEC centers in Van de Werf et al. (2020, in press). Moreover, educational equity subsidy is distributed via the lump sum, not directly retraceable to the children for whom the subsidy is meant, and without specification of how the subsidy should be used. 


\section{Conclusions}

Universal ECEC systems, with a unitary structure (one type of provision for all), early entitlement and generous public spending are thought to be superior in enrolling children from disadvantaged backgrounds from an early age and providing these children with high quality environments for learning and development to compensate for socioeconomic and cultural disadvantages, but the evidence is not conclusive. Recent studies on the quality of the exemplary universal-unitary systems in Denmark and Norway suggest possible drawbacks in this regard: relatively low quality, especially in the educational domain, which is not higher than in non-unitary privatized systems in other countries, patterns of segregated use resulting in lower quality for disadvantaged children, and no clear compensatory effects due to a lack of educational focus and, possibly, commitment to equity.

In addition, the increasing diversification of current societies and, related to that, the increased complexity of the nature and causes of early disadvantages call into question whether 'one size fits all', as in universal unitary systems, and underscore the need for ECEC to be part of networks with other services to meet the diversity of needs and demands of children and families. This critical analysis of publicly funded ECEC systems with the organizational form of, what Mintzberg called, professional bureaucracies can be extended to the primary school system as a similar publicly funded professional bureaucracy which in many countries is no longer the great equalizer it used to be (Lareau 2010; Morabito et al. 2013; Dronkers et al. 2016).

Targeted approaches seem more effective relative to the costs. Costs-benefits analyses reveal a high return on investment of targeted programs. The more targeted (i.e., the higher the risk status of targeted individuals), the higher the return (Reynolds et al. 2011), but there is an important caveat. The narrower the definition of the target group, the smaller the total aggregated impact on society (Barnett 2010; Bartik 2014). In a similar vein, the smaller the number of children targeted by an early educational intervention in a particular area, the smaller the additional social multiplier and spill-over effects. As a synthesis of the findings, we proposed two complementary approaches:

1. A universal within targeted approach in which in designated areas with a moderate to high representation of children who meet the (broadly defined) criteria of target group, universal ECEC of high quality is provided to all children in these areas;

2. A targeted within universal approach in which targeted incentives within a universal ECEC (or, for that matter, primary school) system facilitate organizations with a value-based social-emancipatory mission to reach out to disadvantaged groups and provide children from these groups with compensating high quality education.

The Dutch educational equity policy of the past decades was discussed to illustrate the dilemmas, contradictions and paradoxes that seem inherent to equity policy in the context of hybrid ECEC systems and bureaucratic public education institutions. The two components of this targeted policy, subsidy to primary schools via the lump sum and subsidy to municipalities for areas-policy focusing mainly on ECEC, exemplify how targeted and universal measures can be integrated and may or may not work. The findings regarding the effectiveness of the Dutch equity policy suggest that 
lump sum subsidy to primary schools, including kindergarten for 4- to- 6-year-olds, without specifying how the subsidy should be used, may not be effective. Similar conclusions have been drawn in other countries (Poesen-Vandeputte and Nicaise 2013; Pickett and Vanderbloemen 2015).

The Dutch earmarked areas subsidy with the demand to use the subsidy especially for ECEC-based targeted measures, home-based education programs, and/or the coordination of networks of collaborating services including ECEC, seems more effective. More in specific, through local market dynamics, leading to the emergence of committed missionary ECEC organizations that attract relatively high proportions of disadvantaged children and provide them with inclusive high quality education, the ethical value behind targeting (to compensate for social disadvantages and to redistribute collective wealth) seems to be better served in a hybrid than in a predominantly public system. There is price to be paid. The dynamics of the local market do not prevent and may even increase socioeconomic and ethnic segregation. Also, municipalities differ in policies and political support for an equity agenda, which causes differences in availability, accessibility and quality of ECEC for children with the same needs but living in a different municipality (Turkenburg 2003; Mulder and Meijnen 2013; Van de Kuilen et al. 2020).

Critical to all targeted approaches is the definition of the target group. Criteria should be valid (indicate as directly as possible the proximal causes of educational disadvantages) and the cut-off should be set to include a broad group of children to capitalize on social multiplier and spill-over effects. The Dutch educational policy of the past decades shows how changes in political priorities influence not only the size of the target group, but also the validity of the definition and thereby the efficiency of the policy.

The role of curricula specifically designed for supporting pre-academic and social-emotional development of disadvantaged children is not unambiguous. Simply demanding ECEC organizations and primary schools to work with such a curriculum is unlikely to change practice. The fidelity of the implementation is at serious jeopardy if not supported by an organizational context that, through professional development and inter-collegial support, based on a shared emancipatory mission and felt urgency, ensures implementation as intended. The officially accredited curricula for early childhood education in The Netherlands are as such well-designed, based on state-of-the-art knowledge about early development and learning, while striking a balance between play-based informal learning and intentional instruction in preacademic skills (Ansari and Purtell 2017). But this does not matter if these programs are not implemented as intended.

Funding This study was supported by a grant of the European Union within the Horizon 2020 framework (ISOTIS-project, GA 727069).

Open Access This article is licensed under a Creative Commons Attribution 4.0 International License, which permits use, sharing, adaptation, distribution and reproduction in any medium or format, as long as you give appropriate credit to the original author(s) and the source, provide a link to the Creative Commons licence, and indicate if changes were made. The images or other third party material in this article are included in the article's Creative Commons licence, unless indicated otherwise in a credit line to the material. If material is not included in the article's Creative Commons licence and your intended use is not permitted by statutory regulation or exceeds the permitted use, you will need to obtain permission directly 
from the copyright holder. To view a copy of this licence, visit http://creativecommons.org/licenses/by/4. $0 /$.

\section{References}

Agirdag, O., Van Houtte, M., \& Van Avermaet, P. (2012). Why does the ethnic and socio-economic composition of schools influence math achievement? The role of sense of futility and futility culture. European Sociological Review, 28(3), 366-378.

Akgündüz, Y.E., \& Heijnen, S. (2018). Impact of funding targeted pre-school interventions on school readiness: evidence from the Netherlands. De Economist, 166(2), 115-178.

Akgündüz, Y.E., Ünver, Ö., Nicaise, I., \& Plantenga, J. (2015). The economics of early childhood education and care. CARE Deliverable 5.1. Utrecht: Utrecht School of Economics.

Ansari, A., \& Purtell, K.M. (2017). Activity settings in full-day kindergarten classrooms and children's early learning. Early Childhood Research Quarterly, 38, 23-32.

Barnett, W.S. (2010). Universal and targeted approaches to preschool education in the United States. International Journal of Child Care and Education Policy, 4(1), 1-12.

Bartik, T. J. (2014). From preschool to prosperity: the economic payoff of early childhood education. Kalamazoo: Upjohn Institute for Employment Research. https://doi.org/10.17848/9780880994835.

Bjørnestad, E., \& Os, E. (2018). Quality in Norwegian childcare for toddlers using ITERS-R. European Early Childhood Education Research Journal, 26(1), 111-127. https://doi.org/10.1080/1350293X. 2018.1412051.

Blanden, J., Del Bono, E., McNally, S., \& Rabe, B. (2016). Universal preschool education: the case of public funding with private provision. The Economic Journal, 126, 682-723.

Bleses, D., Højen, A., Justice, L. M., Dale, P.S., Dybdal, L., Piasta, S. B., Markusen-Brown, J., Clausen, M., \& Haghish, E.F. (2018). The effectiveness of a large-scale language and preliteracy intervention: the SPELL randomized-controlled trail in Denmark. Child Development, 89(4), e342-e363. https:// doi.org/10.1111/cdev.12859.

Cascio, E.U. (2017). Does universal preschool hit the target? Program access and preschool impacts (Working paper 23215). Cambridge: National Bureau of Economic Research.

Cascio, E. U., \& Schanzenbach, D.W. (2013). The impact of expanding access to high quality preschool (Working paper 19735). Cambridge: National Bureau of Economic Research.

CBS (2016). Het aandeel achterstandsleerlingen basisonderwijs afgenomen. [The proportion disadvantaged students in primary education has decreased]. Den Haag, Heerlen: Centraal Bureau voor de Statistiek. https://www.cbs.nl/nl-nl/nieuws/2016/07/aandeel-achterstandsleerlingen-basisonderwijsafgenomen.

Claassen, A., \& Mulder, L. (2003). Leerlingen na de overstap. Een vergelijking van vier cohorten leerlingen na de overgang van basisonderwijs naar voortgezet onderwijs met nadruk op de positie van doelgroepleerlingen van het onderwijsachterstandenbeleid. [Students after the transition. A comparison of four cohorts of students with an emphasis on the position of students targeted by the educational equity policy]. Nijmegen: ITS.

Cornelissen, T., Dustmann, C., Raute, A., \& Schönberg, U. (2018). Who benefits from universal child care? Estimating marginal returns to early child care attendance (IZA Discussion Papers, No. 11688). Bonn: Institute of Labor Economics.

Datta Gupta, N., \& Simonsen, M. (2010). Non-cognitive outcomes and universal high quality child care. Journal of Public Economics, 94, 30-43. https://doi.org/10.1016/j.jpubeco.2009.10.001.

Dotterer, A. M., Burchinal, M., Bryant, D., Early, D., \& Pianta, R.C. (2013). Universal and targeted prekindergarten programs: a comparison of classroom characteristics and child outcomes. Early Child Development and Care, 183(7), 931-950.

Driessen, G. (2012). De ambities waargemaakt? De ontwikkeling van de onderwijspositie van de doelgroepen van het onderwijsachterstandenbeleid tussen 1995 en 2011. In G. Driessen (Ed.), De doelgroepen van het onderwijsachterstandenbeleid: ontwikkelingen in prestaties en het advies voortgezet onderwijs (pp. 3-35). Nijmegen: ITS Radboud Universiteit.

Driessen, G. (2015). De wankele empirische basis van het onderwijsachterstandenbeleid. [The shaky empirical basis of the Dutch educational equity policy]. Mens en Maatschappij, 90(3), 221-243. https:// doi.org/10.1557/MEM2015.3.DRIE.

Dronkers, J., Elfers, L., Karsten, S., Van der Velden, R., \& Van de Werfhorst, H. (2016). Groeiende ongelijkheid vraagt om ingrijpen. [Growing inequality calls for intervention]. Socialisme en Democratie, $73(2), 48-53$ 
Felfe, C., Nollenberger, N., \& Rodríguez-Planas, N. (2015). Can't buy mommy's love? Universal childcare and children's long-term cognitive development. Journal of Population Economics, 28, 393-422. https://doi.org/10.1007/s00148-014-0532-x.

Gormley, W. T. (2008). The effects of Oklahoma's Pre-K program on Hispanic children. Social Science Quarterly, 89(4), 916-936.

De Haan, A. K.E., Hoofs, H., Leseman, P.P. M., \& Elbers, E. (2013). Effects of targeted versus mixed preschool and kindergarten on disadvantaged children's emergent academic skills: a cohort-sequential latent growth modeling approach. School Effectiveness \& School Improvement, 24(2), 177-194.

Harms, T., Clifford, R. M., \& Cryer, D. (2005). Early childhood environment rating scale: revised edition $(E C E R S-R)$. New York: Teachers College Press.

Harms, T., Cryer, D., \& Clifford, R. M. (2006). Infant/toddler environment rating scale: revised edition $($ ITERS-R). New York: Teachers College Press.

Havnes, T., \& Mogstad, M. (2015). Is universal child care leveling the playing field? Journal of Public Economics, 127, 100-114.

Heckman, J. J., Moon, S. H., Pinto, R., Savelyev, P. A., \& Yavitz, A. (2010). The rate of return to the High/ Scope Perry Preschool Program. Journal of Public Economics, 94(1-2), 114-128.

Henry, G.T., \& Rickman, D. K. (2007). Do peers influence children's skill development in preschool? Economics of Education Review, 26, 100-112. https://doi.org/10.1016/j.econedurev.2005.09.006.

Højen, A., Bleses, D., Jensen, P., \& Dale, P. S. (2019). Patterns of educational achievement among groups of immigrant children in Denmark emerge already in preschool second-language and literacy skills. Applied Psycholinguistics, 40, 853-875. https://doi.org/10.1017/S0142716418000814.

Van Huizen, T. M. (2018). The evolution of achievement gaps from early childhood to adolescence in the Netherlands. In G. Passaretta \& J. Skopek (Eds.), Roots and development of achievement gaps. A longitudinal assessment in selected European countries (pp. 50-87). Dublin: Trinity College Dublin.

Van Huizen, T., \& Akgündüz, Y.E. (2016). The impact of spending on early childhood education and care on PISA scores. Working paper. Utrecht: Utrecht School of Economics.

Van Huizen, T. M., \& Plantenga, J. (2018). Do children benefit from universal early childhood education and care? A meta-analysis of evidence from natural experiments. Economics of Education Review, 66, 206-222.

Van Huizen, T. M., Duhms, L., \& Plantenga, J. (2019). The costs and benefits of investing in universal preschool: evidence from a Spanish reform. Child Development, 90(3), e386-e406.

Justice, L. M., Petscher, Y., Schatschneider, C., \& Mashburn, A. (2011). Peer effects in preschool classrooms: Is children's language growth associated with their classmates' skills? Child Development, 82(6), 1768-1777.

Kleppe, R., \& Bjørnestad, E. (2019nr). Økt barnehagelaerertetthet og hverdagskvalitet i barnehagen. OsloMet Skriftserie $2019 \mathrm{nr}$ 7. Oslo: Oslo Metropolitan University.

Kottelenberg, M. J., \& Lehrer, S.F. (2017). Targeted or universal coverage? Assessing heterogeneity in the effects of universal child care. Journal of Labor Economics, 35(3), 609-653.

Van Lancker, W., \& Ghysels, J. (2012). Who benefits? The social distribution of subsidized child care in Sweden and Flanders. Acta Sociologica, 55(2), 125-142. https://doi.org/10.1177/0001699311433428.

Van Lancker, W., \& Van Mechelen, N. (2015). Universalism under siege? Exploring the association between targeting, child benefits and child poverty across 26 countries. Social Science Research, 50, $60-75$.

Lareau, A. (2010). Unequal childhoods, class, race, and family life (2nd edn.). Berkeley: University of California Press.

Lee, V.E., Loeb, S., \& Lubeck, S. (1998). Contextual effects of prekindergarten classrooms for disadvantaged children on cognitive development. Child Development, 69(2), 479-494.

Leseman, P.P.M. (1989). Structurele en pedagogische determinanten van schoolloopbanen. [Structural and pedagogical determinants of school careers]. Rotterdam: Rotterdamse Schooladviesdienst.

Leseman, P., \& Veen, A. (2016). Ontwikkeling van kinderen en relatie met kwaliteit van voorschoolse instellingen. Resultaten uit het pre-COOL cohortonderzoek. Rapport 947. Amsterdam: Kohnstamm Instituut.

Leseman, P.P. M., \& Van Tuijl, C. (2001). Home support for bilingual development of Turkish 4-6-yearold immigrant children in the Netherlands: efficacy of a home-based educational program. Journal of Multicultural and Multilingual Development, 21(4), 309-324.

Leseman, P. P. M., Mulder, H., Verhagen, J., Broekhuizen, M., van Schaik, S. D. M., \& Slot, P.L. (2017). Effectiveness of Dutch targeted preschool education policy for disadvantaged children. In H.P. Blossfeld, N. Kulic, J. Skopek \& M. Triventi (Eds.), Childcare, early education, and social inequality-An international perspective (pp. 173-193). Cheltenham: Edward Elgar. 
Magnuson, K., \& Duncan, G. J. (2016). Can early childhood interventions decrease inequality of economic opportunity? Russell Sage Foundation, 2(2), 123-141.

Melhuish, E., \& Gardiner, J. (2017). Study of early education and development (SEED): Study of quality of early years provision in England. Oxford: University of Oxford.

Melhuish, E., Ereky-Stevens, K., Petrogiannis, K., Ariescu, A., Penderi, E., Rentzou, K., \& Leseman, P. (2015). A review of research on the effects of Early Childhood Education and Care (ECEC) upon child development. CARE-project deliverable D4.1. Oxford: Department of Education, University of Oxford.

Mintzberg, H. (1983). Structure in fives: designing effective organizations. Englewood Cliffs: PrenticeHall International Editions.

Morabito, C., Vandenbroeck, M., \& Roose, R. (2013). 'The greatest of Equalisers': a critical review of international organisations' views on early childhood care and education. Journal of Social Policy, 42(03), 451-467. https://doi.org/10.1017/S0047279413000214.

Mulder, L. (1996). Meer voorrang, minder achterstand? Het Onderwijsvoorrangsbeleid getoetst. [More priority, less disadvantage? The Educational Priority Policy tested]. Nijmegen: ITS. doctoral dissertation

Mulder, L., \& Meijnen, W. (2013). Onderwijsachterstanden in de BOPO-periode 2009-2012. Een reviewstudie. [Educational disadvantages in the BOPO-period 2009-2012. A review]. Nijmegen: ITS Radboud Universiteit.

Mulder, H., Hoofs, H., Verhagen, J., Van der Veen, I., \& Leseman, P.P. M. (2014). Psychometric properties and convergent and predictive validity of an executive function test battery for two-year-olds. Frontiers in Psychology, 5, 1-17.

Mulder, H., Verhagen, J., Van der Ven, S., Slot, P. L., \& Leseman, P. P. M. (2017). Executive function at age 2 predicts emergent mathematics and literacy at age 5. Frontiers in Psychology, 8(1706), 1-14.

Naumann, I. (2011). Towards the marketization of early childhood education and care? Recent developments in Sweden and the United Kingdom. Nordic Journal of Social Research, 2, 37-53. https://doi. org/10.7577/njsr.2049

OECD (2006). Starting strong III. Paris: Organization for Economic Cooperation and Development.

Oudgenoeg-Paz, O., \& Leseman, P. (2017). Validering van de VLOT omgevingsanalyse. Eindrapportage. [Validation of the VLOT home learning environment screening. Final report]. Utrecht: Utrecht University, Department of Special Education.

La Paro, K. M., Hamre, B. K., \& Pianta, R.C. (2008). Classroom assessment scoring system pre-K manual. Baltimore: Brookes.

La Paro, K. M., Hamre, B. K., \& Pianta, R.C. (2011). Classroom assessment scoring system toddler manual. Charlottesville: Teachstone.

Pavolini, E., \& Van Lancker, W. (2018). The Matthew effect in child care use: A matter of policies or preferences? Journal of European Public Policy, 25(6), 878-893.

Penn, H. (2011). Gambling on the market: the role of for-profit provision in early childhood education and care. Journal of Early Childhood Research, 9(2), 150-161.

Pickett, K., \& Vanderbloemen, L. (2015). Mind the gap. Tackling social and educational inequality (CPRT Research Survey 4). Cambridge: Cambridge Primary Review Trust.

Poesen-Vandeputte, M., \& Nicaise, I. (2013). Tien jaar GOK decreet. Balans van het evaluatieonderzoek van het gelijke onderwijskansenbeleid in Vlaanderen. Rapport SSL/2012.03/5.1. [Ten years GOK decree. Conclusions of the evaluation research of the educational equity policy in Flanders]. Leuven: Steunpunt Studie- en Schoolloopbanen.

Quinn, J.B., Mintzberg, H., \& James, R. M. (1988). The strategy process, concepts, contexts and cases. Engelwood: Prentice-Hall International Editions.

Reid, J.L., \& Ready, D.D. (2013). High-quality preschool: The socioeconomic composition of preschool classrooms and children's learning. Early Education \& Development, 24(8), 1082-1111.

Reynolds, A. J., Temple, J.A., White, B. A. B., Ou, S. R., \& Robertson, D. L. (2011). Age 26 cost-benefit analysis of the Child-Parent Center early education program. Child Development, 82(1), 379-404.

Scheerens, J. (1987). Enhancing educational opportunities for disadvantaged learners. Amsterdam: NorthHolland Publishing Company.

Skopek, J., \& Passaretta, G. (2018). The evolution of socioeconomic and ethnic inequalities in cognitive achievement from preschool to secondary schooling in the UK. In G. Passaretta \& J. Skopek (Eds.), Roots and development of early achievement gaps: a longitudinal assessment in selected European countries (ISOTIS Report D1.3., pp. 108-157). Dublin: Trinity College Dublin.

Slavenburg, J., \& Peters, T. (1989). Het project Onderwijs en Sociaal Milieu: een eindbalans. [The project Education and Social Background: An end balance]. Rotterdam: Rotterdamse Schooladviesdienst. 
Slot, P., Jepma, Y., Muller, P., Romijn, B., \& Leseman, P. (2018a). Kwaliteit van de Nederlandse kinderdagopvang, peuteropvang, buitenschoolse opvang en gastouderopvang. Gecombineerde metingen 2017-2018. Utrecht: Universiteit Utrecht Sardes.

Slot, P.L., Bleses, D., Justice, L. M., Markussen-Brown, J., \& Højen, A. (2018b). Structural and process quality of Danish preschools: direct and indirect associations with children's growth in language and pre-literacy skills. Early Education and Development, 29, 1-22. https://doi.org/10.1080/10409289. 2018.1452494.

Slot, P.L., Lerkkanen, M.-K., \& Leseman, P.P.M. (2015). The relations between structural quality and process quality in European early childhood education and care provisions: Secondary analyses of large scale studies in five countries. CARE-report D2.2. Utrecht: Utrecht University.

Van Tuijl, C., Leseman, P.P.M., \& Rispens, J. (2001). Efficacy of an intensive home-based educational intervention program for 4-6 year old ethnic minority children in the Netherlands. International Journal of Behavioral Development, 25(2), 148-159.

Turkenburg, M. (2003). Het gemeentelijk onderwijsachterstandenbeleid halverwege de planperiode (1998-2002). [The municipal educational equity policy half-way the plan period (1998-2002)]. The Hague: Sociaal en Cultureel Planbureau.

Ünver, Ö. (2019). Accessibility and inclusiveness of early childhood education and care across Europe. Leuven: Catholic University of Leuven, Institute for Work and Society.

Van der Werf, W. M., Slot, P.L., Kenis, P.N., \& Leseman, P.P.M. (2020). Hybrid organizations in the Dutch privatized and harmonized ECEC system: relations with quality of education and care. Early Childhood Research Quarterly, 53c, 136-150.

Van der Werf, W.M., Slot, P.L., Kenis, P.N., \& Leseman, P.P.M. (under review). Inclusive practice and quality of education and care in the hybrid Dutch early childhood education and care system. Utrecht, The Netherlands: Utrecht University, Department of Child, Family and Education Studies. Manuscript submitted for publication.

Van de Kuilen, L., Leseman, P., \& De Wolf, I. (2020).The influence of local ECEC governance on the quality of preschool education in the Netherlands. Utrecht, The Netherlands: Inspectorate of Education/ Utrecht University, Department of Child, Family and Education Studies.

Vandell, D.L., Belsky, J., Burchinal, M., Steinberg, L., Vandergrift, N., \& NICHD Early Child Care Research Network (2010). Do effects of early child care extend to age 15 years? Results from the NICHD study of early child care and youth development. Child Development, 81(3), 737-756.

Vandenbroeck, M. (2015). Ethnic diversity and social inclusion in ECCE in Europe. In P. T. M. Marope \& Y. Kaga (Eds.), Investing against evidence: the global state of early childhood care and education. Paris: Unesco Publishing.

Veen, A., Roeleveld, J., \& Leseman, P. (2000). Evaluatie van Kaleidoscoop en Piramide. Eindrapportage [Evaluation of the preschool curricula Kaleidoscoop and Piramide. Final report]. Amsterdam: Kohnstamm Instituut.

Veen, A., van der Veen, I., van Schaik, S., \& Leseman, P. (2017). Kwaliteit in kleutergroepen en relatie met de ontwikkeling van kinderen: resultaten uit het pre-COOL cohortonderzoek (Rapport 973). [Quality in kindergarten and the relation with child development: Results of the pre-COOL cohort study]. Amsterdam: Kohnstamm Instituut.

Vermeer, H., Van IJzendoorn, M. H., Cárcamo, R. A., \& Harrison, L. A. (2016). Quality of child care using the environmental rating scales: A meta-analysis of international studies. International Journal of Early Childhood, 48(1), 33-66.

Weiland, C., \& Yoshikawa, H. (2014). Does higher peer socio-economic status predict children's language and executive function skills gains in prekindergarten? Journal of Applied Developmental Psychology, 35, 422-432.

Zachrisson, H.D., \& Ribeiro, L. (2018). Socioeconomic and migration-related inequality in early language development in Norway. In G. Passaretta \& J. Skopek (Eds.), Roots and development of early achievement gaps: A longitudinal assessment in selected European countries (ISOTIS-report D1.3., pp. 88-107). Dublin: Trinity College Dublin. 